Article

\title{
Evaluating Forest Protection Strategies: A Comparison of Land-Use Systems to Preventing Forest Loss in Tanzania
}

\author{
Isabel M.D. Rosa ${ }^{1,2,3, * \mathbb{C}}$, Dennis Rentsch ${ }^{4}$ and J. Grant C. Hopcraft ${ }^{5}$ \\ 1 German Centre for Integrative Biodiversity Research (iDiv), Deutscher Platz 5e, 04103 Leipzig, Germany \\ 2 Institute of Biology, Faculty of Natural Sciences I, Martin-Luther-Universität Halle-Wittenberg, \\ 06120 Halle, Germany \\ 3 School of Natural Sciences, Bangor University, Bangor LL57 2UW, UK \\ 4 Lincoln Park Zoo, 2001 N. Clark St., Chicago, IL 60614, USA; drentsch@lpzoo.org \\ 5 Institute of Biodiversity, Animal Health and Comparative Medicine, University of Glasgow, \\ Glasgow G12 8QQ, UK; grant.hopcraft@glasgow.ac.uk \\ * Correspondence: isabel.rosa@idiv.de or i.rosa@bangor.ac.uk; Tel.: +44-(0)-1248-383-642
}

Received: 16 September 2018; Accepted: 24 November 2018; Published: 28 November 2018

\begin{abstract}
Understanding the effects of forest management strategies is especially important to avoid unregulated natural resource extraction that leads to ecosystem degradation. In addition to the loss of crucial forest services, inefficiencies at converting these natural resources into economic gain for people ultimately exacerbates poverty. Therefore, it is important to know which conservation strategies have proven to be effective in preventing ecosystem degradation and thus be encouraged in future management plans. Here, we used a high-resolution remotely sensed dataset spanning 15 years to study forest cover dynamics across various protected areas in Tanzania. Our findings highlight particular management approaches more effective in preventing forest cover loss and promote forest cover gain, and provide valuable information for conservation efforts. Results show that National Parks have the least forest cover loss, whereas multiple-use Game Controlled Areas have the highest rates of forest loss. In fact, results suggest that these multiple use areas tend to lose more forest cover than areas with no protection or management status at all. These findings suggest the need for more effective strategies for enforcing the existing policies to ensure that socio-economic benefits to local communities are maximized and national interests are sustained.
\end{abstract}

Keywords: sustainable forest management; management areas; African forests; multiple use; conservation; forest cover change

\section{Introduction}

Widespread forest degradation, loss, and exploitation is a global problem with severe consequences and long lasting effects [1-3] on biodiversity [4], on climate [5] - further exacerbating species loss [6] - and livelihoods of those who rely on the resources provided by these ecosystems [7]. According to the last Global Forest Resources Assessment [8], there was a decrease of 1.29 million $\mathrm{km}^{2}$ (3.1\%) of forests worldwide since 1990 through 2015, which has been strongly linked to agricultural expansion [9] driven by the need for feeding a rapidly increasing and resource-demanding human population. In Africa, Hosonuma et al. [3] showed that 70 to $80 \%$ of forest loss was due to agricultural expansion, in particular, small-scale subsistence agriculture. This highlights the need to invest in forest management practices that ensure the sustainability of the resources provided by these ecosystems [10-12]. 
The United Republic of Tanzania (hereafter, Tanzania) is an extremely rich country in natural resources; facing large challenges with $28.2 \%$ of the population living below poverty level. It contains six out of the 25 global biodiversity hotspots [13] but these ecosystems have been under increasing anthropogenic pressure over the last couple of decades. For instance, Milledge et al. [14] estimated that around 0.1 million $\mathrm{km}^{2}$ of forest land was lost between 1970 and 1998; and it has been reported that from 1990 through 2010 Tanzania lost an average of $4034 \mathrm{~km}^{2}$ or 1.0\%/year of its forest cover, resulting in a total loss of $19.4 \%$ of its original cover [15]. The underlying causes of deforestation in the country have been identified as rapid human population growth, the lack of wealth, as well as policy and market failures [16]. In addition, weak government institutions that are unable to enforce existing policies and limited alternative income opportunities for local people have been shown to exacerbate forest loss [17]. These instabilities lead to proximate causes of forest loss, which tend to be driven by clearing for agriculture expansion and associated infrastructure development [18-20], overgrazing and wildfires, which can be aggravated under future climate change [1,21]. Furthermore, Tanzania's predominantly rural population $(70.4 \%)$ relies heavily on fuelwood and charcoal as a source of energy for cooking and heating [22]. Overall, $90 \%$ of the daily energy consumption in the whole country is produced by fuelwood $[23,24]$ which places a large demand on forest products (timber, fuelwood) and exposes forests to rapid over-exploitation.

Apart from forestry, Tanzania's economy is highly dependent on agricultural activities, with a significant portion of the households generating income through this activity [23]. In 2009, the government implemented a new strategy ('Kilimo Kwanza'), aiming to open new land to agriculture and to modernize agricultural techniques (including enhanced finance mechanisms, private investment, and provisioning access to regional markets) [25]. The push to find more fertile agricultural areas and the associated movement of people often leads to the destruction of the natural vegetation [26].

Tanzania has one of the most advanced legal and policy frameworks concerning the management and ownership of forests by rural communities in Africa. Since the late 1990s, forest management has been gradually transferred from the central government to the local communities [16], following a policy approved in 1998 (the National Forestry Policy), which for the first time pushed for a change in the way forests were managed [16]. This was followed in 2002 by the Forest Act [16], which allowed communities to own and manage (or co-manage) forests. As of yet, only a few studies at very local scale, have attempted to understand whether different nationally designated areas have had distinct impacts in the forests. For instance, Blomley et al. [27] revealed that forests under Participatory Forest Management (PFM) showed signs of improving forest condition [14,23]. However, these initial findings need to be assessed at national scale, and not only for PFM initiatives, but also for areas under different land use management.

Tanzania's forests are highly dynamic, and while the stated Mission of the Tanzanian Forest Service is to: "Sustainably manage the National forest and bee resources in order to contribute to the social, economic, ecological and cultural needs of present and future generations", there is a paucity of information on the causes related to the extent and intensity of deforestation [24]. Our hypothesis is that effectiveness in preventing forest loss is linked to the regulated protection level. The main objective of this study is, therefore, to use a time series of 15 years of forest cover change data to understand how the different types of designated areas play a role in determining the rate and location of this change; and investigate potential correlations with drivers, such as agricultural and livestock productivity. Understanding the effects of different types of designated areas, and which are particularly effective in preventing ecosystem degradation is particularly important for developing countries where unregulated natural resource extraction often leads to the degradation of ecosystems and their services. In addition to the loss of crucial forest services, inability at sustainably converting these natural resources into real economic gain for people ultimately exacerbates the poverty spiral. Therefore, it is important to know which conservation strategies should be encouraged in future management plans, as they have proven to prevent ecosystem degradation ensuring sustainable management of natural resources. 


\section{Methods}

\subsection{Study Area}

Tanzania is located in East Africa and is a country that covers an area of $947,303 \mathrm{~km}^{2}$. According to the Forest Resource Assessment in 2015, Tanzania ranks fourth in terms of forest cover when compared to all other African nations, but is the second nation with the largest amount of deforestation in Africa [8]. Within Tanzania we can find five types of biomes, i.e., Mangroves, Flooded Grasslands and Savannas, Mountain Grasslands and Savannas, Tropical and Subtropical Grasslands, Savannas and Shrublands as well as Tropical and Subtropical Moist Broadleaf Forests. Further, the landscape diversity within the country comes also from its 18 ecoregions, for instance Eastern Arc forests, Dry miombo woodlands, and Southern Acacia-Commiphora bushlands and thickets [28].

To prevent ecosystem degradation, there are seven categories of national designated areas in Tanzania (see also Table 1), namely: National Parks (NP), Conservation Areas (CA), Wildlife Management Areas (WMA), Game Reserves (GR), Game Controlled Areas (GCA), State Forest Reserves (SFR) and Village Forests Reserves (VFR) [29]. Regarding the biome coverage of these areas, the majority of land cover within all areas represented the biome Tropical and Subtropical Grasslands, Savannas and Shrublands, except SFR that were mostly within the Tropical and Subtropical Moist Broadleaf Forests. Further, and despite the mixture in vegetation cover, the ecoregion covering the largest proportion of most areas (including 100\% in the CA) was Southern Acacia-Commiphora bushlands and thickets, followed by Dry miombo woodlands [28].

Each of the designated areas allow different land use activities (Table 1). For instance, while Game Reserves allow tourism and hunting only, Game Controlled Areas allow hunting, tourism, settlement, livestock and cultivation [30]. The first WMAs were established in Tanzania in 2006 with the aim of promoting conservation and contributing towards poverty alleviation through sustainable use of natural resources [31]. There has not been a comprehensive analysis on the effectiveness of these areas at the national scale, and [32] argued that more research was needed to understand how these different managing systems can facilitate sustainability in both forest use and livelihoods. 
Table 1. Different categories of designated areas in Tanzania analyzed in this study. Observations regarding permitted land use and ranking of protection. Note: land under no protection or management is referred to in the text by "outside".

\begin{tabular}{cl}
\hline Designation & \multicolumn{1}{c}{ Observations } \\
\hline $\begin{array}{c}\text { National Parks } \\
\text { (NP) }\end{array}$ & National Parks represent the highest level of resource protection that can be provided in Tanzania. \\
\hline $\begin{array}{c}\text { Conservation Areas } \\
\text { (CA) }\end{array}$ & $\begin{array}{l}\text { Areas where conservation of natural resources is the main focus. This is represented only by the Ngorongoro Conservation } \\
\text { Area in Tanzania. Other objectives include safeguarding the interest of indigenous people and promoting tourism. }\end{array}$ \\
\hline $\begin{array}{c}\text { Wildlife Management Areas } \\
\text { (WMA) }\end{array}$ & $\begin{array}{l}\text { Areas where land is set aside for the exclusive purpose of wildlife habitat. Managed by local communities and } \\
\text { village members. }\end{array}$ \\
\hline $\begin{array}{c}\text { Game Reserves } \\
\text { (GR) }\end{array}$ & $\begin{array}{l}\text { Areas created mainly for hunting and tourism purposes. Land use is restricted, but activities related to consumptive and } \\
\text { non-consumptive tourism, research and education are permitted. }\end{array}$ \\
\hline $\begin{array}{c}\text { Game Controlled Areas } \\
\text { (GCA) }\end{array}$ & $\begin{array}{l}\text { Land and resources used for purposes in addition to wildlife. Other activities allowed in these areas include residence, } \\
\text { cultivation, and livestock keeping. }\end{array}$ \\
\hline $\begin{array}{c}\text { State Forest Reserves } \\
\text { (SFR) }\end{array}$ & $\begin{array}{l}\text { Areas created to improve sustainable management of Tanzania's forests under the surveillance of the Central Government. } \\
\text { The goal is to improve the capacity of local managers and increase the production capacity, especially for wood fuel. }\end{array}$ \\
\hline $\begin{array}{c}\text { Village Forests Reserves } \\
\text { (VFR) }\end{array}$ & $\begin{array}{l}\text { Areas where forest management is assumed by the Village leaders and the Village Council. The government owns the land, } \\
\text { but all profits are distributed among the community in charge of the land. }\end{array}$ \\
\hline $\begin{array}{l}\text { Outside } \\
\text { (OUT) }\end{array}$ & Any area under no management plan or protection status \\
\hline
\end{tabular}




\subsection{Data Compilation}

To analyse forest cover change in Tanzania we used the dataset produced by Hansen et al. [33], which spans from 2000 to 2014 (Figure 1). This secondary data (v1.2) include four layers: (1) the percentage (\%) tree cover in 2000; (2) forest loss (classified as 1 where change from forest to non-forest occurred; and 0 otherwise); (3) forest gain (classified as 1 where change from non-forest to forest occurred; and 0 otherwise); and (4) the year of loss (classified as 1 to 14, representing the year when forest loss occurred: from 2001 through 2014). Forest loss is defined by Hansen et al. [33] as "a stand-replacement disturbance, or a change from a forest to non-forest state", whereas forest gain is defined as "the inverse of loss, or a non-forest to forest change entirely within the study period" [33]. It is important to note that this dataset does not distinguish natural forests from plantations, neither forests from woodlands, therefore, interpretation of the results should account for this limitation. We did, however, only consider areas with $>20 \%$ tree cover (following $[34,35]$ ) and higher than $5 \mathrm{~m}$ (part of Hansen's et al. [33] assumptions), thus using a more conservative approach than the definition of a 'forest' by the Food and Agriculture Organization (FAO).

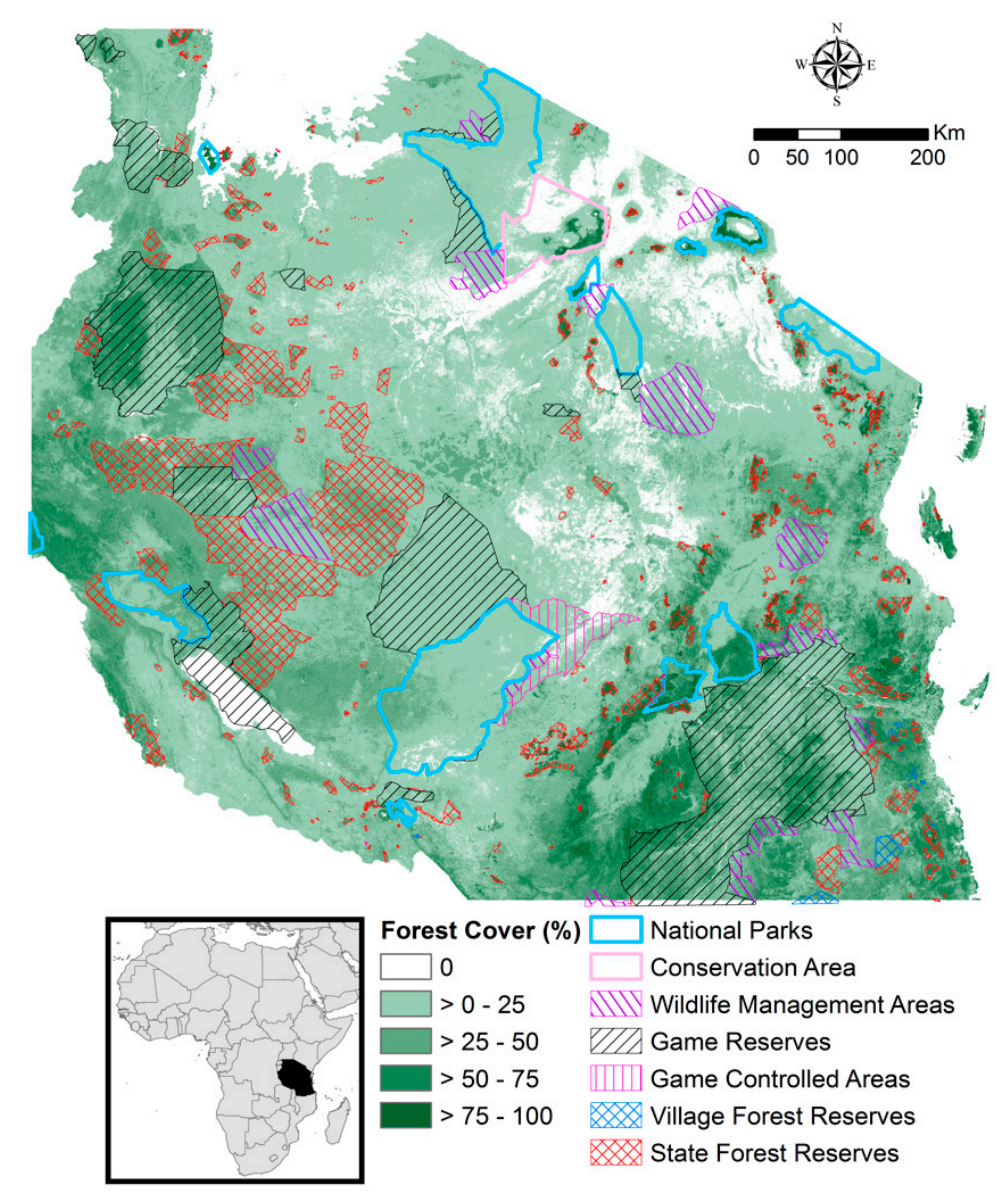

Figure 1. Forest cover (\%) in 2000 in Tanzania and nationally designated categories of protected areas considered in this study (source data: Hansen et al. [33] and World Database of Protected Areas [30]).

From the World Database of Protected Areas [30], we downloaded a shapefile containing the delineation of all areas under protection and/or different management strategies (Table 2). We removed any areas under international designation and focused the analysis on areas under national designation. To avoid double counting forest loss events, where overlaps across categories occurred, the category with highest protection ranking prevailed (Table 1). Once all the data were collected, and projected to the same coordinate system (UTM 36S), it was converted to raster with the same cell size of $30 \mathrm{~m}$ and extent using the maximum combined area method. To test for the effect of the distance to each 
designated area on the rate of forest loss, we used ArcMap [36] to produce buffers of various sizes (from $300 \mathrm{~m}$ through 12,000 m) surrounding each type of designated area, which were also rasterized to $30 \mathrm{~m}$ raster using the same method.

Table 2. List of freely available spatial data layers used in this study. A short description of the dataset is included as well as some specifications such as type, scale and data source.

\begin{tabular}{ccccc}
\hline Name & Detail & Type & Spatialscale & Data Source \\
\hline Forest Cover & $\begin{array}{c}\text { Tree Cover (\%); Forest Loss (overall and } \\
\text { annual) and Gain 2001-2014 }\end{array}$ & raster & $\begin{array}{c}\text { Global } \\
\sim 30 \mathrm{~m}\end{array}$ & Hansen et al. [33] \\
\hline Designated Areas * & $\begin{array}{c}\text { 8 categories } \\
\text { (see Table 1) }\end{array}$ & shapefile & Global & $\begin{array}{c}\text { Protected Planet from } \\
\text { UNEP-WCMC [30] }\end{array}$ \\
\hline Livestock data & Number of head from 2001 through 2008 & tabular & National & $\begin{array}{c}\text { Tanzania National } \\
\text { Bureau of Statistics }\end{array}$ \\
\hline $\begin{array}{c}\text { Agriculture } \\
\text { production }\end{array}$ & $\begin{array}{c}\text { National production } \\
\text { from 2000 through 2013 }\end{array}$ & tabular & National & $\begin{array}{c}\text { Food and Agriculture } \\
\text { Organisation }\end{array}$ \\
\hline $\begin{array}{c}\text { Agricultural Area } \\
\text { Harvested }\end{array}$ & $\begin{array}{c}\text { National area harvested from 2000 } \\
\text { through 2013 }\end{array}$ & tabular & National & $\begin{array}{c}\text { Food and Agriculture } \\
\text { Organisation }\end{array}$ \\
\hline $\begin{array}{c}\text { Forest } \\
\text { production }\end{array}$ & $\begin{array}{c}\text { Wood Fuel Production from 2000 } \\
\text { through 2013 }\end{array}$ & tabular \\
\hline $\begin{array}{c}\text { * designated areas were separated into 2 datasets according to their date of implementation: (1) whole time period } \\
\text { (all areas, except wildlife management areas, which were all implemented post-2006); (2) 2011-2014 (including all } \\
\text { areas, since after 2010 no new areas were created) }\end{array}$ & National & $\begin{array}{c}\text { Food and Agriculture } \\
\text { Organisation }\end{array}$ \\
\hline
\end{tabular}

\subsection{Relative Incidence of Forest Loss and Forest Gain}

To conduct our analyses, we first calculated the overall forest loss and gain, which occurred between 2000 and 2014 in Tanzania. To do so, we determined the initial area of forest cover in 2000 within each designated area and buffer area. This was done by first converting the percentage tree cover $(\%)$ in the 2000 raster into a binary raster (1-forest, 0 -non-forest) following [34]: cells that were deforested between 2001 and 2014 and/or had at least $20 \%$ of the tree cover in 2000 were classified as forest (1) in the 2000 raster dataset; otherwise, they were classified as belonging to the non-forest class (0). Then, we used Zonal Statistics in ArcMap [36] to sum the number of forested pixels within each type of management area and buffer area; and calculated the extent of initial forest area (Table 3). Likewise, to calculate the total area of forest loss and forest gain within each area we summed the number of pixels of forest loss (or forest gain, respectively) that fell within its boundaries (Table 3).

The initial area of forest varies significantly across designated areas (Table 3) and buffer zones; therefore, a straightforward comparison of the amount of loss and gain would not be suitable. We determined the relative incidence of forest loss (RIFL, \%) and forest gain (RIFG, \%) (Equations (1) and (2)) for each feature of interest (i), i.e., in and out each designated area, as well as within the buffers of each area.

$$
\begin{aligned}
& \%_{\text {Loss }_{i}}=\left(\frac{{\text { Forest } \text { Loss }_{i}}_{\text {Forest Area }}}{\text { Fo }}\right) * 100 / / \% \text { Gain }_{i}=\left(\frac{\text { Forest Gain }_{i}}{\text { Forest Area }_{i}}\right) * 100 \\
& \% \text { RIFL }_{i}=\left(\frac{\% \text { Loss }_{i}}{\sum \% \text { Loss }}\right) * 100 / / \% \text { RIFG }_{i}=\left(\frac{\%_{\text {Gain }}}{\sum \% \text { Gain }}\right) * 100
\end{aligned}
$$

Because some designated areas were created post-2000 we performed the analyses of incidence of forest loss and forest gain in two steps: (1) for the whole period 2000-2014, including only the areas created pre-2000 (which excludes all WMAs, but includes $96 \%$ of all areas, and $97 \%$ of the forest area in 2000); (2) 2011-2014 (only for forest loss, because forest gain data is only available as consolidated for the full time period), considering all areas, since according to UNEP World Conservation Monitoring Centre [30], none were created post-2010. This way we could assess how WMAs (all gazetted post-2006) have been performing in comparison the existing, older, designated areas. 
Table 3. Summary statistics (2001-2014) for the different categories of designated areas in Tanzania (based on rasterized data at $30 \mathrm{~m}$ resolution).

\begin{tabular}{|c|c|c|c|c|c|c|}
\hline Designation & $\begin{array}{c}\text { Forest } \\
\text { Area } \\
2000 \\
\left(\mathrm{~km}^{2}\right)\end{array}$ & $\begin{array}{c}\% \text { of } \\
\text { Overall } \\
\text { Forest } \\
2000\end{array}$ & $\begin{array}{c}\text { Forest } \\
\text { Loss } \\
01-14 \\
\left(\mathrm{~km}^{2}\right)\end{array}$ & $\begin{array}{c}\text { Rate of } \\
\text { Loss } \\
\text { (Loss/ } \\
\text { Forest, \%) }\end{array}$ & $\begin{array}{c}\text { Forest } \\
\text { Gain } \\
01-12 \\
\left(\mathrm{~km}^{2}\right)\end{array}$ & $\begin{array}{c}\text { Rate of } \\
\text { Gain } \\
\text { (Gain/ } \\
\text { Forest, \%) }\end{array}$ \\
\hline Conservation Areas & 1537 & 0.4 & 29 & 1.9 & 30 & 1.9 \\
\hline Game Controlled Areas & 506 & 0.1 & 70 & 13.8 & 2 & 0.3 \\
\hline Game Reserves & 62513 & 17.3 & 729 & 1.2 & 48 & 0.1 \\
\hline National Parks & 15589 & 4.3 & 203 & 1.3 & 95 & 0.6 \\
\hline State Forest Reserves & 46873 & 13.0 & 2311 & 4.9 & 226 & 0.5 \\
\hline Village Forests Reserves & 1204 & 0.3 & 24 & 2.0 & 1 & 0.1 \\
\hline Wildlife Management Areas (after 2006) & 9500 & 2.6 & 328 & 3.5 & 19 & 0.2 \\
\hline Outside & 223437 & 61.9 & 18381 & 8.2 & 2003 & 0.9 \\
\hline
\end{tabular}

Finally, analyzing the RIFL over time can help identify strategies that are on a trajectory of increasing rate of forest loss which can be used to inform mitigation policies to prevent further forest loss and ecosystem degradation. Therefore, we also determined the RIFL (\%) by year (between 2001 and 2014) within the different designated areas. Using R, we determined whether the RIFL time series for each type of designated area was temporally auto-correlated; i.e., the rate of forest loss at time ( $\mathrm{t}$ ) is dependent on the rate of forest loss at time ( $\mathrm{t}-1)$ (function auto.arima). We used generalized least squares (GLS) regression to test for a trend (either positive or negative) over time [37]. Unfortunately, the gain in forest cover by year is not available from the Hansen et al. [33] dataset, only the accumulated gain between 2000 and 2012, so the same analysis could not be replicated for forest gain.

\subsection{Forestry and Agricultural Statistical Analyses}

Once we determined how forest cover changed over time within the different designated categories, we then investigated how the observed changes compared to national forestry and agricultural statistics for the same time period (Table 2). From the Statistics Division of the Food and Agriculture Organization [38] we obtained data on forestry production, such as fuelwood production; as well as data on area harvested and agricultural production (by crop type), both from 2000 to 2013. Due to data limitation at sub-national level, we constrained this analysis to the national level, for which we correlated the fuelwood production, as well as the area harvested for agriculture with the time series of forest cover loss between 2001 and 2013. Further, we also perform this correlation with livestock numbers (available only between 1998 and 2008), obtained from the Ministry of Agriculture, Livestock and Fisheries of Tanzania.

\section{Results}

\subsection{Protection Status and Management Category}

In 2000, Tanzania's forests and woodlands covered an area of $361,160 \mathrm{~km}^{2}$, where $34.5 \%$ were within a designated area (Figure 1), of which $12.7 \%$ were State Forest Reserves, $17.1 \%$ were Game Reserves and 4.0\% were National Parks (Table 3). From 2000 to 2014, approximately 21,685 km² (6.0\%) of Tanzania's forests and woodlands have been lost or degraded. By contrast, forest cover increased by only $2361 \mathrm{~km}^{2}(0.7 \%)$ (Table 3$)$, representing nine times more loss than gain over this time period. Despite fluctuating over time (Figure 2), annual forest loss rates have more than doubled in Tanzania from the beginning to the end of the time period studied, i.e., from $887 \mathrm{~km}^{2} /$ year in 2001 to 2100 $\mathrm{km}^{2} /$ year in 2014. On average, there was a forest loss of $1577 \mathrm{~km}^{2} /$ year between 2001 and 2014, or $0.4 \%$ /year $(\mathrm{SD}=0.2 \%)$. 


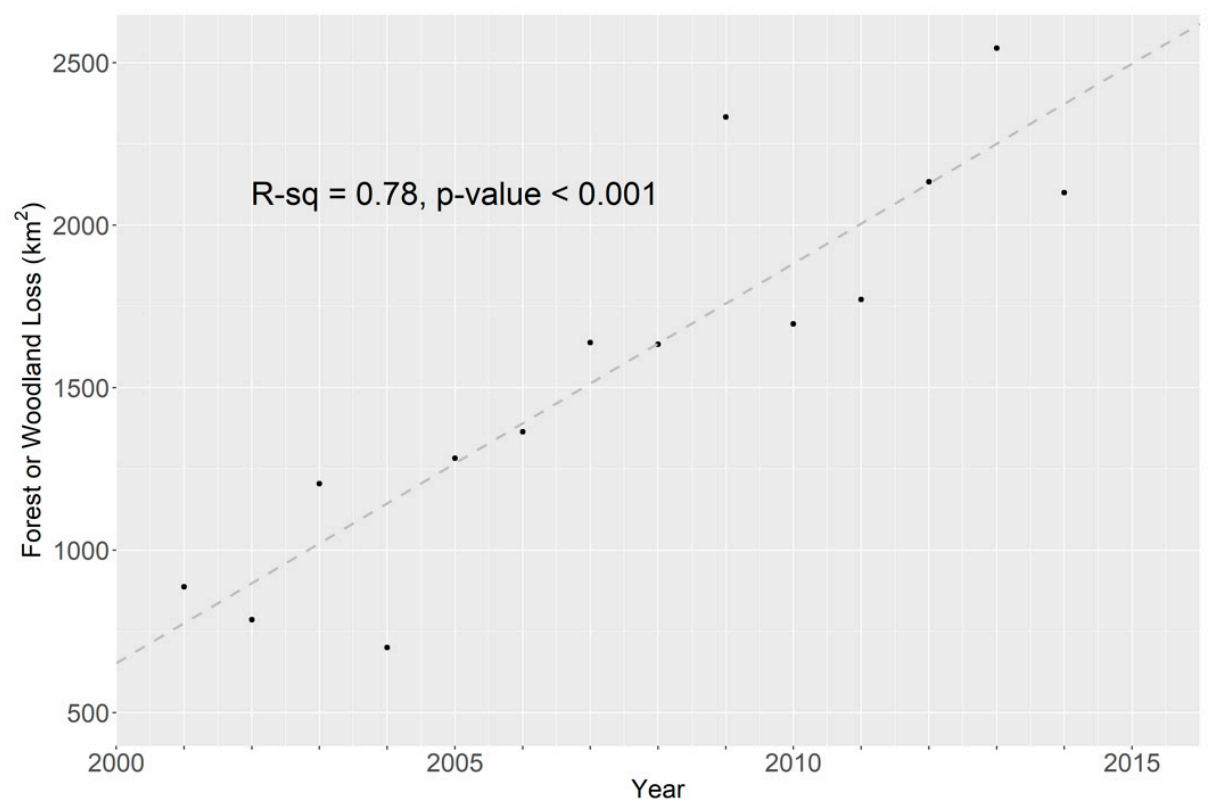

Figure 2. Annual forest and woodland loss $\left(\mathrm{km}^{2}\right)$ between 2001 and 2014 in Tanzania (original source data from Hansen et al. [33]). The dashed line represents the linear regression between the year and the amount of forest lost $\left(\mathrm{R}^{2}=0.80, p<0.001\right)$.

Of the overall forest loss (2001-2014), 84.8\% occurred in areas under no protection or management (Figure 3a), followed by 10.6\% in State Forest Reserves and 3.3\% inside Game Reserves. Likewise, the majority of forest gain occurred in areas under no management $(84.9 \%)$, followed by $8.5 \%$ in State Forest Reserves and 3.3\% inside National Parks (Figure 3a). We found that between 2001 and 2014 the highest RIFL occurred in Game Controlled Areas followed by non-designated areas and State Forest Reserves. On the other hand, the highest RIFG occurred in Conservation Areas (Figure 3b), followed by Outside and National Parks. When analyzing 2011-2014, which considered all designated areas, we assessed that the newly created Wildlife Management Areas positioned themselves roughly in the middle of both the overall loss and the RIFL rankings (Figure 3c,d), with $1.0 \%$ of the overall loss, and $8.7 \%$ of RIFL.

We found that Game Controlled Areas almost consistently had the greatest annual RIFL over time, with the exception of the last three years (Figure 4a,b). Further, RIFL increased significantly in State Forest Reserves $(\beta=0.80, p=0.001)$ and in Village Forest Reserves $(\beta=0.62, p=0.05)$. No significant trend was found in the remaining designations, both considering the complete time period (2001-2014) and the recent one (2011-2014). Aggregating the different management strategies, we found that exploitation areas (Game Controlled Areas + Village Forest Reserves + State Forest Reserves + Outside) had more than triple the forest area of preservation areas (National Parks + Conservation Areas + Game Reserves) in 2000. Moreover, we found that both forest loss and forest gain (in absolute area) was higher in exploitation areas than in preservation areas, although the difference was much more substantial in terms of loss (more than 20-fold) than gain (nearly 15-fold). However, should differences could be inflated as an artifact of the gain algorithm requiring significant forest cover growth to get above the gain threshold [33]. Concordantly, we found that the rate of forest loss was six and a half times higher in exploitation areas $(7.7 \%)$ compared to preservation areas $(1.2 \%)$. 

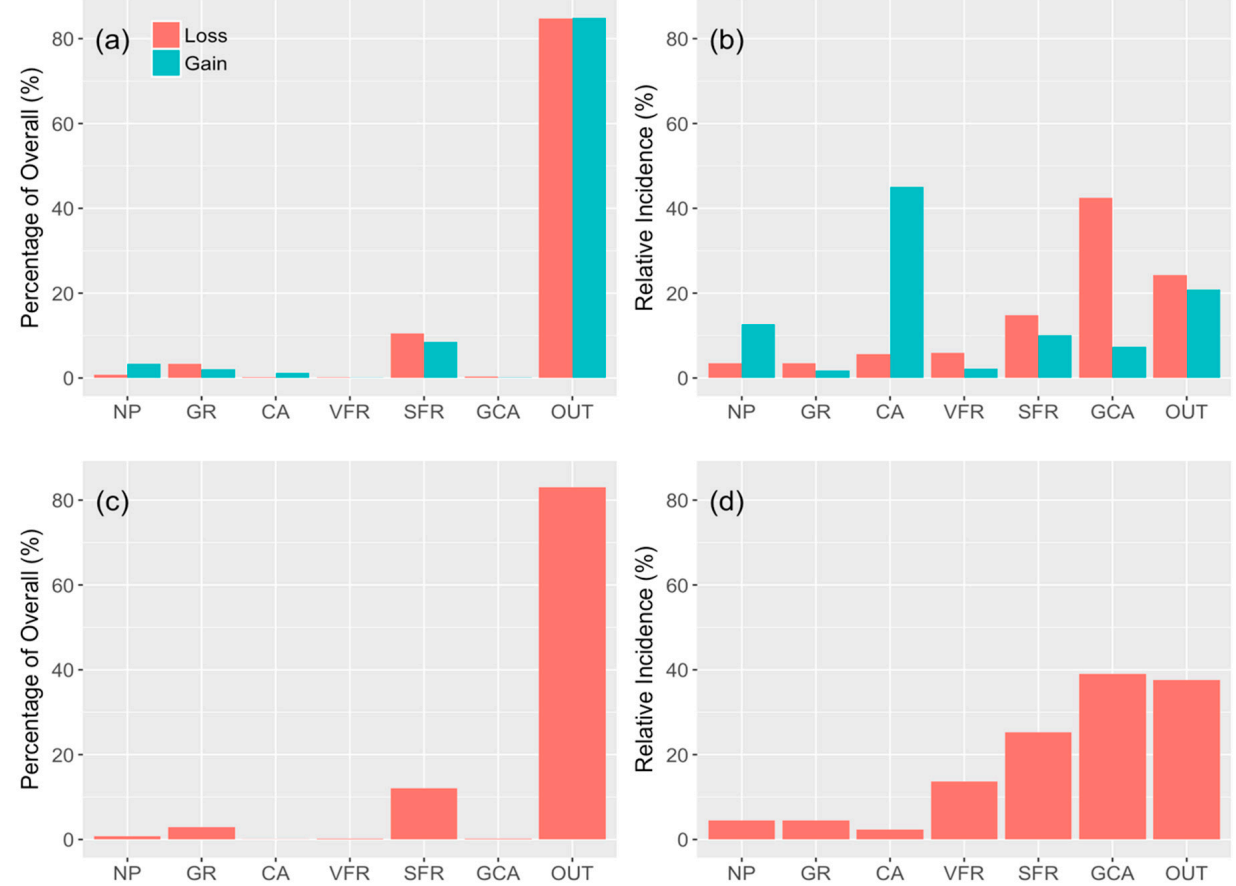

Figure 3. Percentage of overall forest loss and forest gain and relative incidence of forest loss and forest gain by land management and protection status, respectively for $(\mathbf{a}, \mathbf{b})$ only the areas designated before 2001 (2001-2014); and (c,d) all areas (2011-2014). Note: National Parks (NP), Conservation Areas (CA), Wildlife Management Areas (WMA), Game Reserves (GR), Game Controlled Areas (GCA), State Forest Reserves (SFR), Village Forests Reserves (VFR), Outside (OUT).
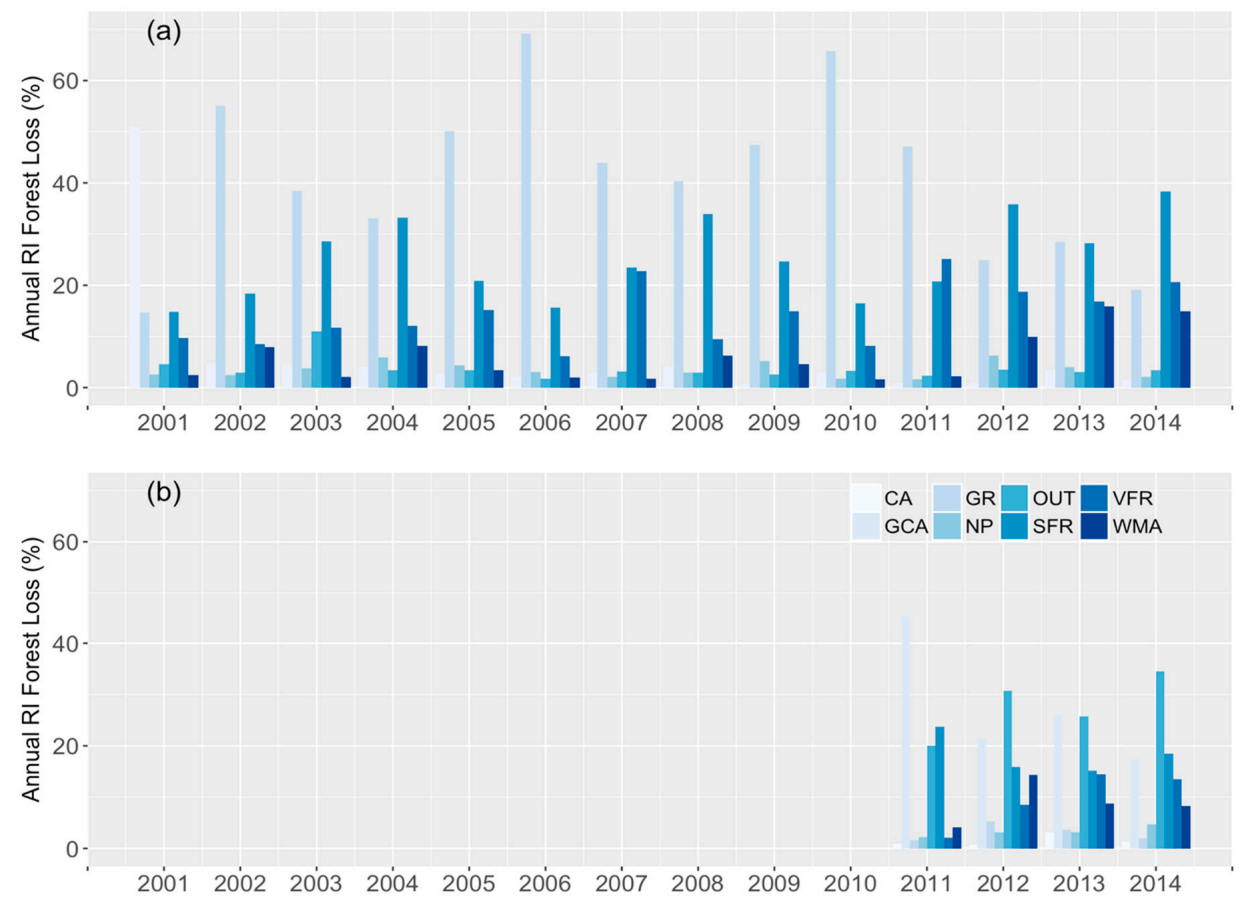

Figure 4. Relative Incidence of Forest Loss (RIFL) within each type of management area for (a) the period between 2001 and 2014 (all areas created pre-2001), and (b) the period between 2011 and 2014, containing all types of management areas. Note: National Parks (NP), Conservation Areas (CA), Wildlife Management Areas (WMA), Game Reserves (GR), Game Controlled Areas (GCA), State Forest Reserves (SFR), Village Forests Reserves (VFR), Outside (OUT). 


\subsection{Distance to Protected or Managed Areas}

Using buffers of different sizes, we evaluated how the RIFL and the RIFG varied with the distance to each category of designated areas, within the period from 2001 through 2014 (Figure 5a,b), and between 2011 and 2014 (Figure 5c). From 2001 through 2014, apart from Game Controlled Areas, RIFL was always higher outside than inside these areas (Figure 5a). Further, we found that RIFL was not only higher inside these areas but also close to its boundaries (Figure 5a), when compared to all other designations. The value of RIFL decreased with the increasing distance to their borders, in contrast with the remaining designations. In recent years (2011-2014, Figure 5c), the patterns were similar, with greater loss outside than inside, and the recently created Wildlife Management Areas positioning themselves within the observed trends (more loss outside than inside). Regarding the RIFG, we found that the highest values occurred near the Conservation Area and close to National Parks (Figure 5b), although these results might be correlated given that the only Conservation Area in Tanzania is located right next one of the largest national parks (Serengeti). Regarding forest gain, we found an increasing trend in RIFG relative to the buffer distance, i.e., forest gains occurring further away from Village Forest Reserves, Game Reserves and Game Controlled Areas.
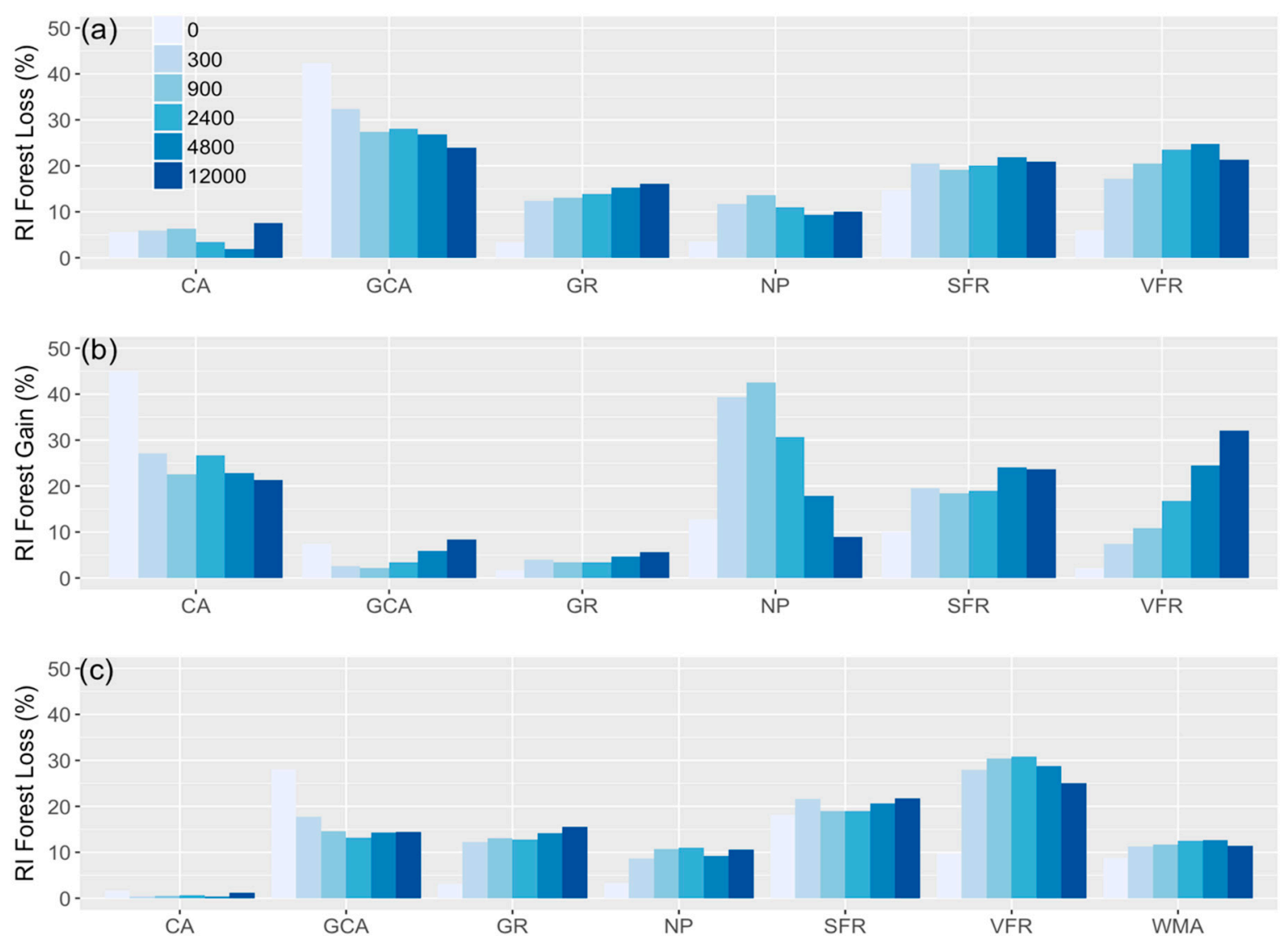

Figure 5. Relative Incidence of Forest Loss (RIFL) and Forest Gain (RIFG) inside, and within a distance (from $300 \mathrm{~m}$ up to $12,000 \mathrm{~m}$ ) of each protected or management area, compared to the outside, (a,b) for the period 2001-2014; (c) for the period 2011-2014. Note: National Parks (NP), Conservation Areas (CA), Wildlife Management Areas (WMA), Game Reserves (GR), Game Controlled Areas (GCA), State Forest Reserves (SFR), and Village Forests Reserves (VFR).

In both periods, Game Reserves, National Parks and Village Forest Reserves registered the highest forest cover dynamics on their boundaries (three to four times higher RIFL and RIFG within the $300 \mathrm{~m}$ buffer than inside). Furthermore, we found that the gap between forest loss in preservation areas and 
exploitation areas, peaked in both time periods at the shortest distance $(300 \mathrm{~m})$ for forest loss; and a longer distance $(12 \mathrm{~km})$ for forest gain.

\subsection{Agricultural and Forestry Dynamics}

In the 2000s there was a 15\% growth in forestry production, and a strong correlation (Figure 6a) between overall forest loss (2001-2013) and fuelwood production (Pearson's $r=0.90, p<0.001$ ), as well as whole logs $(r=0.91, p<0.001)$. Whole logs represent $48 \%$ of the production and fuelwood represents $44 \%$. These shares have been stable over time. Moreover, we found a strong positive correlation (Figure $6 \mathrm{~b}, \mathrm{c}$ ) between area of forest loss and area harvested for agriculture $(\mathrm{r}=0.83$, $p<0.001)$, and with agricultural production $(\mathrm{r}=0.76, p<0.05)$. We found that between 2000 and 2013 the total area harvested increased by $136 \%$, and the production by $127 \%$. By 2013 , the area harvested in Tanzania was mainly dominated by cereals $(20.9 \%)$, followed by maize $(13.8 \%)$ and oil crops $(11.5 \%)$. The change between 2000 and 2013 was sharp, with the area harvested for maize increasing by $305 \%$, for oil crops by $192 \%$ and for cereals by $145 \%$. Unfortunately, spatial data on agricultural/forestry areas is unavailable in Tanzania with the level of detail used in the forest dynamics analysis. Finally, livestock production has also increased significantly between 1998 and 2008 (26\%, no data available after 2008), and we found a significant correlation between forest loss and cattle production at the national level $(\mathrm{r}=0.80, p=0.05)$.
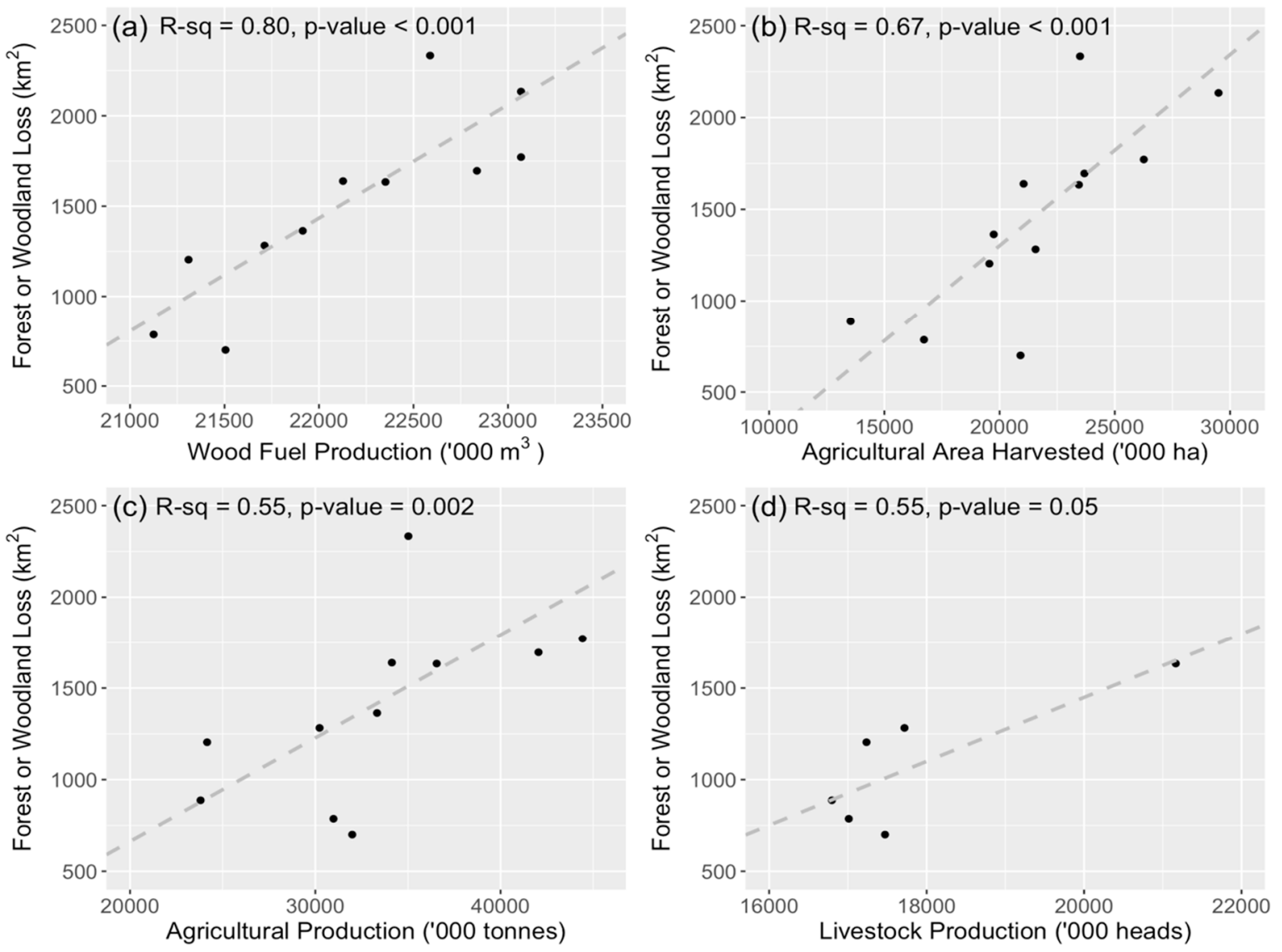

Figure 6. Correlation between forest loss $\left(\mathrm{km}^{2}\right)$ that occurred in Tanzania between 2001 and 2013 and (a) wood fuel production ('000 $\left.\mathrm{m}^{3}\right)$, (b) agricultural area harvested ('000 ha), (c) agricultural production ('000 tones), and (d) livestock production, given by the number of head (only between 2001 and 2008, due to data availability). The dashed lines represent the linear fit ( $\mathrm{R}^{2}$ inset) between each two variables. 


\section{Discussion}

Our spatially- and temporally-explicit study is the first to compare the eight different forms of protected status at the national level in Tanzania across 15 years. Our results indicate that National Parks and Conservation Areas had the lowest Relative Incidence of Forest Loss (RIFL), while Game Controlled Areas have the highest RIFL. In addition, the greatest loss in Game Controlled Areas occurred within the core protected area rather than on the edges, which is counter to all other conservation regimes. This suggests that there has been significant forest loss occurring inside these areas despite regulations, i.e., these appear to be ineffective in conserving forests. Conversely, National Parks and Conservation Areas had the greatest relative rates of forest gain (RIFG) and appear to have the largest effect in terms of securing the integrity of forest ecosystems.

Although the most successful form of management is one in which there is $100 \%$ protection (i.e., no utilization, such as National Parks and Conservation Areas), this management excludes local communities from accessing forest resources and therefore may not always be the best socio-economic solution especially for supporting rural livelihoods. The results suggest that although Forest Reserves have greater rates of forest loss than gain, there is still some forest regeneration occurring. This regeneration in forest reserves may partially be due to Participatory Forest Management (PFM) initiatives, which aim to: (i) improve forest quality and its sustainability; (ii) improve the livelihood of those who rely on these forests, by increasing revenues and contributing to their subsistence; and (iii) improve forest governance, focusing on accountable management [27]. Currently, there are only a few PFM agreements signed between the government and the local communities [16], which may explain why we only observed partial regeneration in Forest Reserves. Further empirical research could verify if this strategy may indeed enable a sustainable solution to managing forests in which harvest rates equal regeneration rates resulting in a zero-sum game.

Our analysis found different rates of forest loss (RIFL) and gain (RIFG) within designated areas (Figure 3), suggesting that national governance strategies play an important role in determining forest cover dynamics. National Parks and Conservation Areas not only derive revenue from tourism, but importantly are managed by a single parastatal authority. Management of Game Controlled Areas, by contrast falls under multiple agencies, with communities having little authority, and no single agency standing to benefit directly from forestry gains. Game Controlled Areas appear to be the most extreme form of the tragedy of the commons [39], where there are exceptionally high rates of forest loss across all years with very low rates of forest gain, resulting in the forests in these areas being depleted very rapidly.

Differences in the amount of financial resources invested in designated areas [40] is likely also an important factor explaining the forest dynamics. For example, the annual budget available to National Parks and Conservation Areas is an order of magnitude more than Forest Reserves. As a result, the money that can be allocated to enforcement in the core protected areas is greater, which combined with high densities of tourists, may provide sufficient security against illegal wood harvesting in these areas. Conversely, the management mandate in Forest Reserves is to preserve natural habitats and to help sustain local community livelihoods through the sale and use of wood forest resources. Therefore, the combination of a predefined timber harvesting policy (such as clear-cutting) and less financial resources to enforce regulation likely result in greater rates of forest loss in Forest Reserves than National Parks. This interpretation is confirmed by our results, which suggest that forest gain is particularly high inside National Parks and Conservation Areas, whereas forest loss is greater than forest gain in Forest Reserves (Figure 3b). Unfortunately, information about alternate sources of revenue and annual budgets was not possible to compile at the national level.

The differences in forest loss could also be driven by fire management policies, as the source data does not allow to distinguish clear cut activities from complete vegetation removal by fires. In Tanzania, typically, fires are used to maintain grasslands and improve grazing quality for herbivores in National Parks and for livestock in shared land use areas. Most fires occur early in the dry season and tend to be cool, consuming primarily moribund grass rather than canopy fires that kill trees [41]. 
Evidence suggests that these fires can retard seedling establishment and combined with elephants they can maintain an open savanna state [42]. In many of Tanzania's National Parks such as the Serengeti, between 20 and $40 \%$ of the area is typically burnt every year. Although fires may account for some of the forest loss we observed, our results suggest that this is out-weighted by forest gain in natural systems such as National Parks. Illegal charcoal production is a common form of forest degradation in sub-Sahara African [43] and likely accounts for many of the thermal anomalies in the remote sensing products such as the Active Fire Mapper. The smoke from illegal kilns may be more rapidly detected, reported and followed-up in well financed areas such as National Parks which may also account for the variation we observe between designated areas.

This study also found that the rates of RIFL tended to be highest on the edge of the GCAs, suggesting that the neighboring agriculture and livestock may be spilling over into these areas. National Parks and Conservation Areas, by contrast, had higher RIFL along their edges, suggesting that while they are better able to enforce protection of forests within their core areas, they may be contributing to creating "hard-boundaries" between these and adjacent protected areas, or village land. Such differences may be linked to the characteristics of the places where these areas are located (in terms of accessibility, climate, socio-economic dynamics), which should be further analyzed in future studies.

The more recently created Wildlife Management Areas (WMAs) aimed at promoting a sustainable land use while helping to alleviate poverty by allowing greater governance and responsibilities by local communities [44]. Due to data limitations, we were not able to analyze forest gains within these areas; however, when analyzing forest loss, the results showed that these have a similar rates of forest loss to Village Forest Reserves. In theory, WMAs should protect natural habitats better than reserves, as they are intended to conserve wildlife, provide tourism opportunities and have restrictions on forest exploitation. These preliminary results suggest that that is not the case, but, a more detailed assessment with longer time-series is needed to evaluate the success of these areas in achieving their proposed conservation goals. In addition, wildlife areas are often adjacent to village land zoned for agriculture and livestock grazing, which may impact the outcome of our analysis.

Along with an observed increase in the rate of forest loss, we showed an increase in forestry production, livestock and agricultural production, which will have undeniable impacts on the landscape of Tanzania. Illegal logging, and associated road building, is widespread in the country [32] and external market pressure creates an incentive to unsustainably harvest the forests. Unfortunately, from the existing data we cannot derive the proportion of forest loss due to legal exploitation (timber stands) vs. illegally harvests from protected forests, however, reports suggest this may be greater than previously estimated [14]. Although we were only able to assess these trends at a national level rather than by wards (due to data limitations), the relationship suggests expanding markets for forest and agriculture products poses a threat to the future of Tanzania's forests as in other countries [45].

It is important to stress that our study focused only on forest cover dynamics, not addressing other types of land cover that might be important in the region, such as grasslands for pasture. Furthermore, the data provided by Hansen et al. [33], which essentially detects a range in reflection from the vegetation cover, does not distinguish plantations from natural forest, and reporting forest gains from satellite imagery is much more challenging than forest loss. Moreover, and a particular challenge in East Africa where a large proportion of the land is covered by Miombo Woodlands, is to separate these from forests, as the former represent a mixture of dense forest cover $(>75 \%)$ and open woodlands with a forest cover of $>25 \%$ and $<75 \%$ ). This is further aggravated by the lack of systematic forest inventories and mapping capabilities for many African countries. A new dataset [46], based on the height of the vegetation represents an advancement to potentially better distinguish different land covers but is still rather spatially coarse $\left(0.05^{\circ}\right)$ to be able to improve Miombo detection. Therefore, our results should be interpreted carefully and in light of what is known of the different designated areas. For instance, the loss and gain for forest cover within National Parks is more likely to be related natural processes, such as elephant damage and fires, whereas the loss and gain of forest cover in 
reserves may be attributed to the result of a silviculture practices, such as harvest and plantations of non-native species.

From a national perspective, $60 \%$ of the remaining forest in Tanzania is still not under any specific form of management ("outside designated area"); with only 3.95\% of the forest under the highest, and most successful, form of protection (National Parks). Forest Reserves, which tend to have a more sustainable resource use [14,23], only contained $13 \%$ of the remaining forest area. Tanzania is experiencing a significant increasing trend in the annual rate of forest loss (Figure 1) suggesting the speed at which forests are disappearing is increasing every year. This can have potentially irreversible economic and ecological consequences $[47,48]$, and limits the possibility of Tanzania achieving the Convention on Biological Diversity's Aichi Biodiversity Targets of reducing the rate of habitat loss (including forest) by half before 2020 .

Although the analysis was performed for Tanzania, our findings may have a wider impact by highlighting management strategies more effective in preventing forest loss and promoting forest gain. If developing nations are considering how to best protect their forests and woodlands, then our results suggest that National Parks, if applied with similar legislation as in Tanzania, seem to be the most efficient way, whereas areas which fall under multiple management authorities (e.g., Game Controlled Areas) are the least effective way. Our study further suggests that forests that do best tend to have alternate sources of income other than wood to support them (e.g., National Parks versus Forest Reserves), and have strong governing bodies that are responsible and held accountable for forest health. The high turn-over rate (of loss and gain) within the Forest Reserves suggest that local governance tends to increase sustainability of forest resources. Correlations found between forest loss and agricultural conversion, and wood fuel production indicates that once an area is logged, the largest threats preventing restoration tend to be the subsequent conversion to agriculture. Therefore, it is necessary to invest in clear enforcement, monitoring and adaptive management to accommodate for the consequences of such land use change activities.

Author Contributions: I.M.D.R. designed the analysis with the support of D.R. and J.G.C.H. I.M.D.R. performed all analyses. I.M.D.R. wrote the first draft of the manuscript, which was thoroughly revised by D.R. and J.G.C.H.

Acknowledgments: I.M.D.R. has received funding from the European Union's Horizon 2020 research and innovation program under the Marie Sklodowska-Curie grant agreement No. 703862. We thank the three anonymous reviewers for insightful suggestions that led to the improvement of our manuscript.

Conflicts of Interest: The authors declare no conflict of interest.

\section{References}

1. Bonan, G.B. Forests and climate change: Forcings, feedbacks, and the climate benefits of forests. Science 2008, 320, 1444-1449. [CrossRef] [PubMed]

2. Miles, L.; Kapos, V. Reducing greenhouse gas emissions from deforestation and forest degradation: Global land-use implications. Science 2008, 320, 1454-1455. [CrossRef] [PubMed]

3. Hosonuma, N.; Herold, M.; De Sy, V.; De Fries, R.S.; Brockhaus, M.; Verchot, L.; Angelsen, A.; Romijn, E. An assessment of deforestation and forest degradation drivers in developing countries. Environ. Res. Lett. 2012, 7, 044009. [CrossRef]

4. Maxwell, S.L.; Fuller, R.A.; Brooks, T.M.; Watson, J.E.M. Biodiversity: The ravages of guns, nets and bulldozers. Nature 2016, 536, 143-145. [CrossRef] [PubMed]

5. Lawrence, D.; Vandecar, K. Effects of tropical deforestation on climate and agriculture. Nat. Clim. Chang. 2015, 5, 27-36. [CrossRef]

6. Harley, C.D. Climate change, keystone predation, and biodiversity loss. Science 2011, 334, 1124-1127. [CrossRef] [PubMed]

7. Ferreira, J.; Gardner, T.; Guariguata, M.R.; Koh, L.P.; Okabe, K.; Pan, Y.; Schmitt, C.B.; Tylianakis, J.M.; Barlow, J.; Kapos, V.; et al. Forest Biodiversity, Carbon and Other Ecosystem Services: Relationships and Impacts of Deforestation and Forest Degradation; International Union of Forest Research Organizations (IUFRO): Vienna, Austria, 2012; ISBN 978-3-902762-17-7. 
8. MacDicken, K.G. Global Forest Resources Assessment 2015: What, why and how? For. Ecol. Manag. 2015, 352, 3-8. [CrossRef]

9. Kissinger, G.; Herold, M. Drivers of Deforestation and Forest Degradation: A Synthesis Report for REDD+ Policymakers; Lexeme Consulting: Vancouver, BC, Canada, 2012.

10. Foley, J.A.; Asner, G.P.; Costa, M.H.; Coe, M.T.; DeFries, R.; Gibbs, H.K.; Howard, E.A.; Olson, S.; Patz, J.; Ramankutty, N. Amazonia revealed: Forest degradation and loss of ecosystem goods and services in the Amazon Basin. Front. Ecol. Environ. 2007, 5, 25-32. [CrossRef]

11. Girona, M.M.; Lussier, J.-M.; Morin, H.; Thiffault, N. Conifer regeneration after experimental shelterwood and seed-tree treatments in boreal forests: Finding silvicultural alternatives. Front. Plant Sci. 2018, 9, 1145. [CrossRef] [PubMed]

12. Grandpré, L.; Waldron, K.; Bouchard, M.; Gauthier, S.; Beaudet, M.; Ruel, J.-C.; Hébert, C.; Kneeshaw, D. Incorporating Insect and Wind Disturbances in a Natural Disturbance-Based Management Framework for the Boreal Forest. Forests 2018, 9, 471. [CrossRef]

13. URT. Fifth National Report on Implementation of the Convention of Biological Diversity; United Republic of Tanzania: Dar es Salaam, Tanzania, 2014.

14. Milledge, S.A.; Gelvas, I.K.; Ahrends, A. Forestry, Governance and National Development: Lessons Learned from a Logging Boom in Southern Tanzania; Traffic East/Southern Africa: Dar es Salaam, Tanzania, 2007.

15. Ridder, R.M. Global Forest Resources Assessment 2010: Options and Recommendations for a Global Remote Sensing Survey of Forests; FAO Resour Assess Programme Work Paper; FAO: Rome, Italy, 2007; Volume 141.

16. Blomley, T.; Iddi, S. Participatory Forest Management in Tanzania; Lessons Learned and Experiences to Date; Ministry of Natural Resources and Tourism: Dar es Salaam, Tanzania, 2009.

17. Kukkonen, M.; Käyhkö, N. Spatio-temporal analysis of forest changes in contrasting land use regimes of Zanzibar, Tanzania. Appl. Geogr. 2014, 55, 193-202. [CrossRef]

18. Dobson, A.P.; Borner, M.; Sinclair, A.R.; Hudson, P.J.; Anderson, T.M.; Bigurube, G.; Davenport, T.B.; Deutsch, J.; Durant, S.M.; Estes, R.D.; et al. Road will ruin Serengeti. Nature 2010, 467, 272-273. [CrossRef] [PubMed]

19. Hopcraft, J.G.C.; Bigurube, G.; Lembeli, J.D.; Borner, M. Balancing conservation with national development: A socio-economic case study of the alternatives to the Serengeti road. PLoS ONE 2015, 10, e0130577. [CrossRef] [PubMed]

20. Kessy, J.F.; Nsokko, E.; Kaswamila, A.; Kimaro, F. Analysis of Drivers and Agents of Deforestation and Forest Degradation in Masito Forests, Kigoma, Tanzania. Int. J. Asian Soc. Sci. 2016, 6, 93-107. [CrossRef]

21. Liu, Y.; Stanturf, J.; Goodrick, S. Trends in global wildfire potential in a changing climate. For. Ecol. Manag. 2010, 259, 685-697. [CrossRef]

22. Akida, A.; Mnangwone, I.; Lyimo, L. Financing for Sustainable Fores $\mathrm{t}$ Management in Tanzania. Ind. For. Intell. 2012, 1-52.

23. Kangalawe, R.Y.; Lyimo, J.G. Population dynamics, rural livelihoods and environmental degradation: Some experiences from Tanzania. Environ. Dev. Sustain. 2010, 12, 985-997. [CrossRef]

24. Rija, A.; Kideghesho, J.; Mwamende, K.; Selemani, I. Emerging issues and challenges in conservation of biodiversity in the rangelands of Tanzania. Nat. Conserv. 2013, 6, 1. [CrossRef]

25. URT. The Kilimo Kwanza Resolution and 10 Pillars of Implementation; Ministry of Agriculture, Food Security and Cooperatives: Dar es Salaam, Tanzania, 2009.

26. Salerno, J.D.; Mulder, M.B.; Kefauver, S.C. Human migration, protected areas, and conservation outreach in Tanzania. Conserv. Biol. 2014, 28, 841-850. [CrossRef] [PubMed]

27. Blomley, T.; Pfliegner, K.; Isango, J.; Zahabu, E.; Ahrends, A.; Burgess, N. Seeing the wood for the trees: An assessment of the impact of participatory forest management on forest condition in Tanzania. Oryx 2008, 42, 380-391. [CrossRef]

28. Dinerstein, E.; Olson, D.; Joshi, A.; Vynne, C.; Burgess, N.D.; Wikramanayake, E.; Hahn, N.; Palminteri, S.; Hedao, P.; Noss, R. An ecoregion-based approach to protecting half the terrestrial realm. BioScience 2017, 67, 534-545. [CrossRef] [PubMed]

29. UNEP-WCMC and IUCN. The World Database on Protected Areas (WDPA); UNEP-WCMC and IUCN: Cambridge, UK, 2018. 
30. Thirgood, S.; Mosser, A.; Tham, S.; Hopcraft, G.; Mwangomo, E.; Mlengeya, T.; Kilewo, M.; Fryxell, J.M.; Sinclair, A.R.; Borner, M. Can parks protect migratory ungulates? The case of the Serengeti wildebeest. Anim. Conserv. Forum 2004, 7, 113-120. [CrossRef]

31. Mwakaje, A.G. Wildlife Management Areas in Tanzania: A Study of Opportunities and Challenges. Tanzan. J. Dev. Stud. 2008, 8. [CrossRef]

32. Mbwambo, L.; Eid, T.; Malimbwi, R.E.; Zahabu, E.; Kajembe, G.C.; Luoga, E. Impact of decentralised forest management on forest resource conditions in Tanzania. For. Trees Livelihoods 2012, 21, 97-113. [CrossRef]

33. Hansen, M.C.; Potapov, P.V.; Moore, R.; Hancher, M.; Turubanova, S.A.; Tyukavina, A.; Thau, D.; Stehman, S.V.; Goetz, S.J.; Loveland, T.R.; et al. High-resolution global maps of 21st-century forest cover change. Science 2013, 342, 850-853. [CrossRef] [PubMed]

34. Heino, M.; Kummu, M.; Makkonen, M.; Mulligan, M.; Verburg, P.H.; Jalava, M.; Räsänen, T.A. Forest Loss in Protected Areas and Intact Forest Landscapes: A Global Analysis. PLoS ONE 2015, 10, e0138918. [CrossRef] [PubMed]

35. Potapov, P.; Hansen, M.C.; Stehman, S.V.; Loveland, T.R.; Pittman, K. Combining MODIS and Landsat imagery to estimate and map boreal forest cover loss. Remote Sens. Environ. 2008, 112, 3708-3719. [CrossRef]

36. ESRI. ArcMap 10.1. Computer Software; ESRI: Redlands, CA, USA, 2010.

37. R Core Team. R: A Language and Environment for Statistical Computing; R Foundation for Statistical Computing: Vienna, Austria, 2018.

38. Food and Agriculture Organization. FAOSTAT Database; Food and Agriculture Organization of the United Nations: Rome Italy, 2016; Volume 1.

39. Ostrom, E. Tragedy of the commons. In The New Palgrave Dictionary of Economics; Palgrave Macmillan: New York, NY, USA, 2008.

40. Ferraro, P.J.; Pattanayak, S.K. Money for nothing? A call for empirical evaluation of biodiversity conservation investments. PLoS Biol. 2006, 4, e105. [CrossRef] [PubMed]

41. Morrison, T.A.; Holdo, R.M.; Anderson, T.M. Elephant damage, not fire or rainfall, explains mortality of overstorey trees in Serengeti. J. Ecol. 2016, 104, 409-418. [CrossRef]

42. Holdo, R.M.; Holt, R.D.; Fryxell, J.M. Grazers, browsers, and fire influence the extent and spatial pattern of tree cover in the Serengeti. Ecol. Appl. 2009, 19, 95-109. [CrossRef] [PubMed]

43. Chidumayo, E.N. Forest degradation and recovery in a miombo woodland landscape in Zambia: 22 years of observations on permanent sample plots. For. Ecol. Manag. 2013, 291, 154-161. [CrossRef]

44. Wilfred, P. Towards Sustainable Wildlife Management Areas in Tanzania. Trop. Conserv. Sci. 2010, 3, $103-116$. [CrossRef]

45. Mertens, B.; Poccard-Chapuis, R.; Piketty, M.-G.; Lacques, A.-E.; Venturieri, A. Crossing spatial analyses and livestock economics to understand deforestation processes in the Brazilian Amazon: The case of Sao Felix do Xingu in South Para. Agric. Econ. 2002, 27, 269-294.

46. Song, X.-P.; Hansen, M.C.; Stehman, S.V.; Potapov, P.V.; Tyukavina, A.; Vermote, E.F.; Townshend, J.R. Global land change from 1982 to 2016. Nature 2018, 560, 639. [CrossRef] [PubMed]

47. Balmford, A.; Bruner, A.; Cooper, P.; Costanza, R.; Farber, S.; Green, R.E.; Jenkins, M.; Jefferiss, P.; Jessamy, V.; Madden, J.; et al. Economic reasons for conserving wild nature. Science 2002, 297, 950-953. [CrossRef] [PubMed]

48. Foley, J.A.; DeFries, R.; Asner, G.P.; Barford, C.; Bonan, G.; Carpenter, S.R.; Chapin, F.S.; Coe, M.T.; Daily, G.C.; Gibbs, H.K.; et al. Global consequences of land use. Science 2005, 309, 570-574. [CrossRef] [PubMed]

(C) 2018 by the authors. Licensee MDPI, Basel, Switzerland. This article is an open access article distributed under the terms and conditions of the Creative Commons Attribution (CC BY) license (http://creativecommons.org/licenses/by/4.0/). 